\title{
Validação de radioimunoensaio para quantificação de leptina plasmática bovina
}

\author{
Maria Paula BELTRAN ${ }^{1}$ \\ Guilherme de Paula \\ NOGUEIRA ${ }^{2}$
}

\begin{abstract}
Correspondência para:
Maria Paula Beltran, Rua Rubião Júnior, 3232, ap. 122, Centro, São José do Rio Preto-SP, CEP: 15010-090, (17) 3121

9632; (17) 81236191

mpbeltran@yahoo.com
\end{abstract}

Recebido para publicação: 12/04/2007 Aprovado para publicação: 29/10/2009

\author{
1- Médica Veterinária, Doutora em Reprodução Animal \\ 2- Laboratório de Fisiologia e Endocrinologia Animal da Universidade \\ Estadual Paulista, Araçatuba-SP
}

\section{Resumo}

Devido à necessidade de compreender melhor as interaçóes entre leptina e reproduçáo, um RIA específico para a leptina bovina foi validado. Primeiro, um protocolo para produção de anticorpos foi desenvolvido por meio da inoculaçáo de leptina recombinante equina em um coelho, que resultou em $28,05 \%$ de ligação máxima (MB) 105 dias após o inicio do protocolo. Os testes de validação verificaram paralelismo entre a curva-padráo e as diluiçóes dos controles alto e baixo $(p<0,01)$. O anticorpo contra leptina equina mostrou especificidade para a leptina bovina $(\mathrm{p}<0,01)$. A taxa de recuperaçáo da leptina bovina pelo anticorpo contra leptina recombinante equina foi de 98,4 a 101,6\% ( $<<0,01)$. Quando as amostras foram armazenadas à temperatura ambiente ou refrigeradas a $4^{\circ} \mathrm{C}$, foi verificado estabilidade de ligação $(p>0,2)$, no entanto, temperaturas acima de $37^{\circ} \mathrm{C}$ interferiram negativamente na recuperação da leptina bovina. $\mathrm{O}$ uso do tampáo de ensaio com ou sem a adição de plasma não apresentou diferenças $(\mathrm{p}>0,3)$. Esses resultados demonstraram que o anticorpo produzido em coelho contra leptina equina foi capaz de detectar a leptina plasmática bovina, e que o RIA para a quantificação da leptina bovina apresentou características adequadas para o desenvolvimento de um ensaio válido.

\section{Introdução}

A descoberta da leptina trouxe mudanças nos campos da endocrinologia, nutriçáo e metabolismo. Esta proteína de $16 \mathrm{kDa}$, produzida pelos adipócitos, age como sinalizador metabólico sobre as reservas corporais para o sistema nervoso central ${ }^{1,2,3,4}$. Para melhor compreender o papel fisiológico da leptina, a quantificação precisa e sensível de sua concentração nos fluidos corporais, como soro e plasma, se fez necessária. Vários pesquisadores desenvolveram radioimunoensaios utilizando anticorpos policlonais contra leptina recombinante humana ${ }^{5}$, bovina ${ }^{4,6}$ e ovina ${ }^{7,8}$. Para que um sistema de quantificação hormonal seja válido são necessários alguns controles, como a especificidade, acurácia, sensibilidade e precisão, alem de testes de paralelismo, de estabilidade, de efeito matriz e de recuperação para completar a validaçáo. O ensaio deve ser padronizado quanto ao volume dos reagentes utilizados, quantidade de antígeno marcado com o radioisótopo, tempo e temperatura dos períodos de incubação. Todos os ensaios devem incluir uma curva-padrão e controles. Os controles devem ser incluídos no início, meio e fim de todos os ensaios, de maneira a detectar variaçóes relacionadas às amostras envolvidas ${ }^{8}$. Muitas vezes a validação de um ensaio é negligenciada. Normalmente, modificaçôes dos protocolos são suficientes, em outros casos, mudanças mais radicais, 
como a adequação de algum reagente. A validação requer tempo já que é necessário colher e comparar um grande número de amostras para se chegar a conclusóes validas. Isto é, entretanto, imperativo para a correta validação de um RIA ${ }^{10,11}$. Assim, o objetivo deste experimento foi a validação de um radioimunoensaio específico para a leptina bovina, utilizando o anticorpo antileptina equina produzido através de protocolo de inoculação de leptina em coelhos. Todo o trabalho foi desenvolvido no Laboratório de Fisiologia e Endocrinologia Veterinária do curso de Medicina Veterinária da UNESP de Araçatuba.

\section{Materiais e Métodos}

Produção de anticorpo antileptina equina: Para a validação do ensaio, primeiramente foi produzido o anticorpo específico, por meio da inoculação em coelho de leptina recombinante equina $(r$-eLEP $)$. De acordo com o fabricante (Protein Laboratories Rehovot Ltd -PLR), esta leptina apresenta grande homologia com a leptina recombinante bovina $(r-b L E P)$, o que possibilitou utilizá-la na produção dos anticorpos contra a leptina bovina. Foi usado um coelho macho da raça Nova Zelândia, inicialmente com idade aproximada de oito meses, pesando cerca de $3,5 \mathrm{~kg}$, mantido no Laboratório de Experimentação Animal do Curso de Medicina Veterinária da UNESP de Araçatuba, em ambiente de iluminação (12 $\mathrm{h}$ de luz e $12 \mathrm{~h}$ de escuridão) e temperatura $\left(25^{\circ} \mathrm{C}\right)$ controlados. Os animais eram alimentados com ração comercial e água à vontade.

Para a inoculação primária, foram utilizadas $100 \mu \mathrm{g}$ por animal de $r$-eLEP diluída $1 \mathrm{mg} / 5 \mathrm{ml}$ em água destilada e emulsionada com igual volume de Adjuvante de Freund Completo (solução antígena emulsificada em óleo mineral. A forma completa contém micobactérias, usualmente $M$. tuberculosis, suspensas na fase óleo, e a forma incompleta não contém micobactérias.) (Sigma ${ }^{\oplus}$ cód. F-5881). A partir da segunda inoculação, utilizou-se a mesma concentração de $r-e L E P$, emulsionada com Adjuvante de Freund Incompleto (Sigma ${ }^{\oplus}$, cód. F-5506). Todas as inoculaçóes foram feitas por via subcutânea e em diferentes locais de aplicação. A segunda e a terceira inoculaçóes ocorreram com intervalos de 15 dias e a partir da quarta inoculação, o intervalo passou a ser de 30 dias. Após a quarta inoculação, iniciouse a coleta de sangue da veia auricular do coelho, para a verificação da resposta ao antígeno através de testes de ligação, por radioimunoensaio (RIA).

Iodacão da leptina equina: Em função da provável homologia com a $r-b L E P$, a $r$-eLEP foi marcada com o radioisótopo Iodo 125 (I125) no processo chamado de iodação. $\mathrm{Na}$ iodação, o $\mathrm{I}^{125}$ liga-se a $r$-eLEP, utilizada a partir de então como marcador do ensaio. Tal processo, desenvolvido de acordo com o método Iodogen ${ }^{\oplus}(1,3,4,6$ tetracloro 3a, 5a-diphenilglicuril-Sigma Company ${ }^{\oplus}$, descrito por Salacinski ${ }^{12}$, foi realizado no Laboratório de Endocrinologia do Curso de Medicina Veterinária da UNESP de Araçatuba.

Testes de ligação: Foram comparados o anticorpo produzido contra $r$-eLEP e o anticorpo anti $r-b L E P$ fornecido pelo INRA ${ }^{8}$, buscando definir qual a diluição em que o anticorpo específico se ligou à $r$-eLEP iodada, originando porcentagem de ligaçáo máxima (MB) entre 20 e 30\%. Para isso, utilizaramse somente os tubos TC (contagem total), NSB (ligação não específica) e MB. Aos tubos NSB foram adicionados $300 \mathrm{ml}$ de tampão de incubação $\left(\mathrm{KH}_{2} \mathrm{PO} 0,01 \mathrm{M}\right.$, $\mathrm{Na}_{2} \mathrm{HPO}_{4} 0,01 \mathrm{M}, \mathrm{NaCl}$, Gelatina $1 \%$, $\mathrm{NaN}_{3}$, Tween 20) e $100 \mathrm{ml}$ de soro do coelho que foi inoculado, diluído $(1: 10 ; 1: 50 ; 1: 100$; $1: 300 ; 1: 500 ; 1: 750$ e $1: 1000)$. A todos os tubos foram adicionados $100 \mathrm{ml}$ de $r$-eLEP iodada. Após incubação por 24 horas a $4^{\circ} \mathrm{C}$, foram acrescentados $100 \mathrm{ml}$ de anticorpo inespecífico 1:30 (antigamaglobulina de coelho diluída em PBS EDTA 0,01M) e polietileno glicol (PEG) 6\%, permanecendo os tubos por mais 3 horas à temperatura ambiente.Em seguida, foram centrifugados a $4^{\circ} \mathrm{C}$ e a radioatividade remanescente lida em contador gama (Cobra II - Packard ${ }^{\oplus}$ ) 
por $1 \mathrm{~min} /$ tubo. Os testes de ligação foram realizados também para a determinação dos volumes dos reagentes, da atividade do hormônio marcado e dos períodos de incubação utilizados para o ensaio. Para a interpretaçáo dos resultados, obtidos em CPM, que consiste da radiação emitida por minuto durante a leitura dos tubos, foi calculada a porcentagem de ligação, onde o valor em CPM da NSB foi subtraído do valor em CPM da $\mathrm{MB}$ e o resultado dividido pelo valor em CPM do TC e então multiplicado por 100 [(MB - NSB/TC)*100].

Diluição da curva-padrão de $r$-bLEP e r-eLEP: Foram preparadas curvas-padrão tanto com $r$-eLEP quanto com $r$-bLEP, a partir de diluiçóes seriadas da solução estoque para a obtenção dos pontos com as seguintes concentraçóes: $0,125 \mathrm{ng} / \mathrm{ml} ; 0,25 \mathrm{ng} / \mathrm{rnl} ; 0,5$ $\mathrm{ng} / \mathrm{rnl} ; 1,0 \mathrm{ug} / \mathrm{rnl} ; 2,0 \mathrm{ng} / \mathrm{m} 1 ; 4,0 \mathrm{ng} / \mathrm{rnl} ; 8,0$ $\mathrm{ng} / \mathrm{rnl}$ e $10 \mathrm{ng} / \mathrm{m} 1$. As curvas confeccionadas com $r$-bLEP e $r$-eLEP foram comparadas posteriormente em testes de ligação.

Testes de validação: Depois de estabelecidas as diluiçôes do anticorpo específico e não específico e dos outros reagentes utilizados na confecção do ensaio, assim como os tempos e temperaturas de incubação em cada fase, pelos testes de ligação, foram realizados testes para validação do RIA para quantificação de leptina bovina. Todos os testes. foram realizados com as amostras em duplicata e repetidos três vezes, obedecendo às concentrações, volumes, temperaturas e períodos de incubação determinados.

Protocolo para quantificação de leptina: Inicialmente, $100 \mathrm{ml}$ de cada ponto da curva-padrão e dos controles alto (plasma de vaca gorda, escore de condição corporal 4) e baixo (plasma de vaca magra, escore de condição corporal 1) foram pipetados em tubos de borossilicato $(12 \times 75)$ contendo $300 \mathrm{ml}$ de tampão de incubação, seguido da adição de $100 \mathrm{ml}$ do anticorpo específico (1:500) a todos os tubos, exceto NSB. Nestes adicionaram-se somente o tampão de incubação e o $S N C$, e aos MBs somente tampão de incubação e primeiro anticorpo, e foram incubados por $48 \mathrm{~h} \mathrm{a} 4^{\circ} \mathrm{C}$. Todos os tubos receberam $100 \mathrm{ml}$ de $r$-eLEP iodada (aproximadamente $10.000 \mathrm{CPM}$ ) e foram incubados por $24 \mathrm{~h}$ a $4^{\circ} \mathrm{C}$. Após esse período, adicionou-se $100 \mathrm{ml}$ do anticorpo inespecífico 1:30 e $500 \mathrm{ml}$ de PEG 6\%, e foram incubados por $12 \mathrm{~h}$ e depois centrifugados para a separação do antígeno ligado ao anticorpo do não ligado por meio de precipitação. A centrifugação foi feita por $30 \mathrm{~min}$ a $4^{\circ} \mathrm{C}$ e $2.620,8 \mathrm{xg}$. Os tubos foram entáo colocados em racks de espuma e invertidos para desprezar o sobrenadante, permanecendo invertidos para secar por pelo menos $30 \mathrm{~min}$ sobre papel absorvente. A radioatividade remanescente foi lida em contador gama por $1 \mathrm{~min} /$ tubo.

Teste de paralelismo: Para avaliar se a variação na quantidade de hormônio da amostra alterou a porcentagem de ligaçáo do anticorpo anti-r-eLEP à $r$-eLEP-iodada, foi elaborado o teste de paralelismo. O controle alto e o controle baixo foram diluídos a 100; $50 ; 25 ; 12,5$ e 6,25\% em solução tampão de incubaçáo e comparados com o $\log$ da dose dos pontos da curva-padrão confeccionada com leptina bovina.

Testes de especificidade: Os testes de especificidade avaliaram a capacidade do anticorpo contra $r$-eLEP se ligar à leptina bovina. O primeiro teste comparou a ligação do anticorpo contra $r$-eLEP aos pontos das curvas-padrão, confeccionadas com $r$ - $b L E P$ ou com $r$-eLEP. No segundo teste comparouse a ligaçáo do anticorpo anti- $r$-eLEP com a ligaçáo do anticorpo anti- $r-b L E P$ desafiados com curva-padrão elaborada com $r$ - $b L E P$.

Testes de estabilidade: Com o objetivo de avaliar a interferência da variação no tempo e na temperatura sobre a concentração de leptina plasmática durante a realização dos ensaios, fracionou-se uma amostra de plasma bovino em várias alíquotas, submetidas a diferentes temperaturas por vários períodos de tempo. No primeiro teste (A), uma alíquota foi submetida à temperatura ambiente $\left(26^{\circ} \mathrm{C}\right)$ por $30 \mathrm{~min} ; 1 ; 2 ; 4$ ou $7 \mathrm{~h}$. No segundo teste (B), a amostra foi exposta a $40^{\circ} \mathrm{C}$ ("banho-maria"), por $1 ; 2$ ou $4 \mathrm{~h}$. No terceiro teste $(\mathrm{C})$, a amostra permaneceu por $1 ; 2 ; 3$ ou 4 dias refrigerada a $4^{\circ} \mathrm{C}$. 
Taxa de recuperação ou teste de exatidão: Para estimar qual a porcentagem da identificação da $r$-bLEP pelo anticorpo específico foi realizado o teste de recuperação. Para isso, adicionaram-se quantidades definidas de $r$ - $b L E P$ suspendida em tampão de incubação, e quantificada por RIA.

Teste de efeito matriz: Existe a possibilidade de ocorrer uma ligação inespecífica entre proteínas do plasma bovino e o complexo antígeno-anticorpo, aumentando a formação do precipitado e a quantidade do hormônio marcado com $\mathrm{I}^{125}$ no fundo do tubo. Esse efeito, denominado de efeito matriz, foi avaliado por meio da comparação de duas curvas-padrão com $r$-bLEP, uma diluída somente em tampáo de incubação e outra em tampão de incubação adicionado de 100 /II de plasma bovino com baixa concentração de leptina bovina por tubo, o mesmo volume de plasma utilizado no ensaio. Este teste submeteu a curvapadrão acrescida de plasma bovino às mesmas condiçóes encontradas nos tubos contendo as amostras a serem quantificas, fornecendo as mesmas condições de ligação das encontradas na presença das proteínas no plasma.

A comparação das porcentagens de ligação entre as diluiçóes do soro do coelho inoculado com $r$-eLEP e as diluiçóes do anticorpo anti $r$-bLEP fornecido pelo INRA foi feita pelo teste de Mann Whitney.
Os testes de especificidade, paralelismo e efeito matriz, foram avaliados pelo teste de correlação linear de Pearson. Os testes de estabilidade foram avaliados pela ANOVA. Todos os testes utilizaram o programa GraphPad InStat 3.00 for Windows 95, GraphPad Software, San Diego, Califórnia, EUA. Em todos os testes de validação, exceto o teste de exatidão, utilizou-se a porcentagem de ligação ao invés da dose do hormônio porque nem todas as amostras apresentaram leitura da dose (ng/ml). Fixou-se um erro alfa de 5\% para todas as análises.

\section{Resultados}

Produção de anticorpo anti r-eLEP: A variação na diluição do plasma do coelho inoculado com $r$-eLEP, alterou a porcentagem de ligação, e no momento da $\sigma^{\mathrm{a}}$ inoculação, 105 dias após o início das inoculações, a utilização do plasma deste coelho diluído a 1:500, resultou em $28,08 \%$ de MB. Náo houve diferença $(\mathrm{P}>0,8)$ no $\mathrm{MB}$ entre o anticorpo contra $r$-eLEP $(28,05 \%)$ ou contra $r$-bLEP $(25,7 \%)$ na diluição $1: 500$.

Teste de paralelismo: A variação na porcentagem de ligação dos pontos da curva-padrão e as diluiçóes seriadas dos controles alto $(3 \mathrm{ng} / \mathrm{ml})$ e baixo $(0,25 \mathrm{ng} /$ $\mathrm{ml})$ resultaram em curvas de deslocamento paralelas (Figura 1). Houve correlação entre a

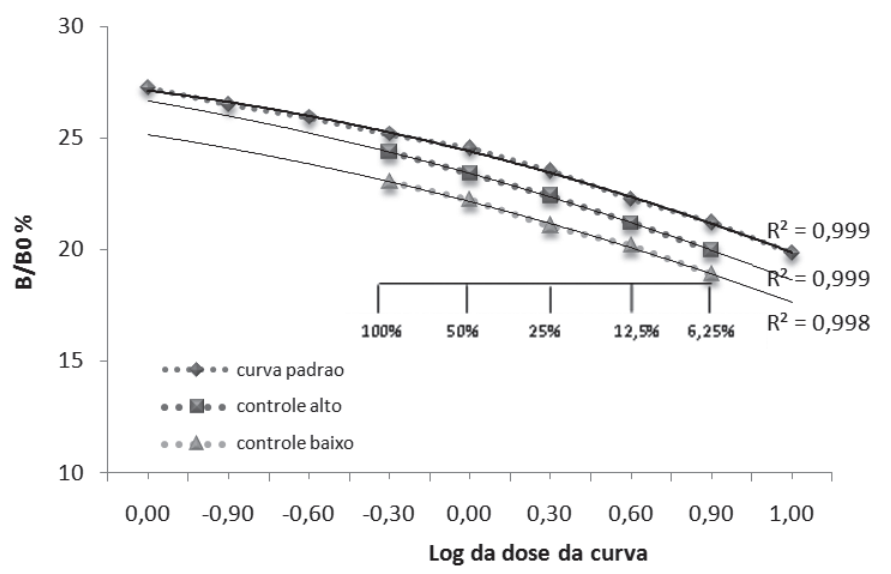

Figura 1 - Teste de paralelismo entre a curva-padrão confeccionada com $r$-bLEP e diluições seriadas com 100 ; $50 ; 25 ; 12,5 ; 6,25 \%$ do volume dos controles alto $(3 \mathrm{ng} / \mathrm{ml})$ e baixo $(0,25 \mathrm{ng} / \mathrm{ml})$ de plasma bovino diluídos em tampão de incubação, em ensaio utilizando anticorpo anti- r-eLEP 
porcentagem de ligação dos pontos da curva e a diluição do controle alto $(\mathrm{r}=0,996 ; \mathrm{P}<$ $0,01)$ e entre os pontos da curva e a diluiçáo do controle baixo $(\mathrm{r}=0,990 ; \mathrm{P}<0,01)$.

Testes de especificidade: Quando os pontos das curvas padrão elaboradas com $r$-bLEP ou $r$-eLEP foram comparados em ensaio utilizando anticorpo anti- $r$-eLEP, foi verificado maior deslocamento da porcentagem de ligaçáo da r-eLEP iodada ao utilizarmos a curva confeccionada com $r$-bLEP. Esse deslocamento se deu de maneira semelhante, mas não paralela, à curva elaborada com r-eLEP (Figura 2A). Houve correlação $(\mathrm{r}=0,974 ; \mathrm{P}<0,01)$ entre os valores das porcentagens de ligação das duas curvas. De maneira semelhante aos resultados anteriores, após comparar a porcentagem de ligação dos pontos da curva-padrão elaborada com $r$-bLEP em ensaios utilizando anticorpo anti-r-bLEP e anti-r-eLEP, observou-se maior porcentagem de ligação dos pontos da curva-padrão elaborada com $r-b L E P$ ao anticorpo anti-r-eLEP (Figura 2B). Nesse caso, as porcentagens de ligação das curvas foram paralelas e apresentaram correlação ( $\mathrm{r}$ $=0,996 ; \mathrm{P}<0,01)$.

Testes de estabilidade: No primeiro teste, onde a amostra permaneceu à temperatura ambiente por $30 \mathrm{~min}, 1 ; 2 ; 4$ ou $7 \mathrm{~h}$ e no terceiro teste, onde a amostra permaneceu por $1 ; 2 ; 3$ ou 4 dias a $4^{\circ} \mathrm{C}$ antes de ser quantificada, não foram detectadas diferenças na variação da porcentagem de ligação $(P>0,2)$. Já no segundo teste, onde o plasma bovino foi submetido à temperatura elevada $\left(40^{\circ} \mathrm{C}\right)$
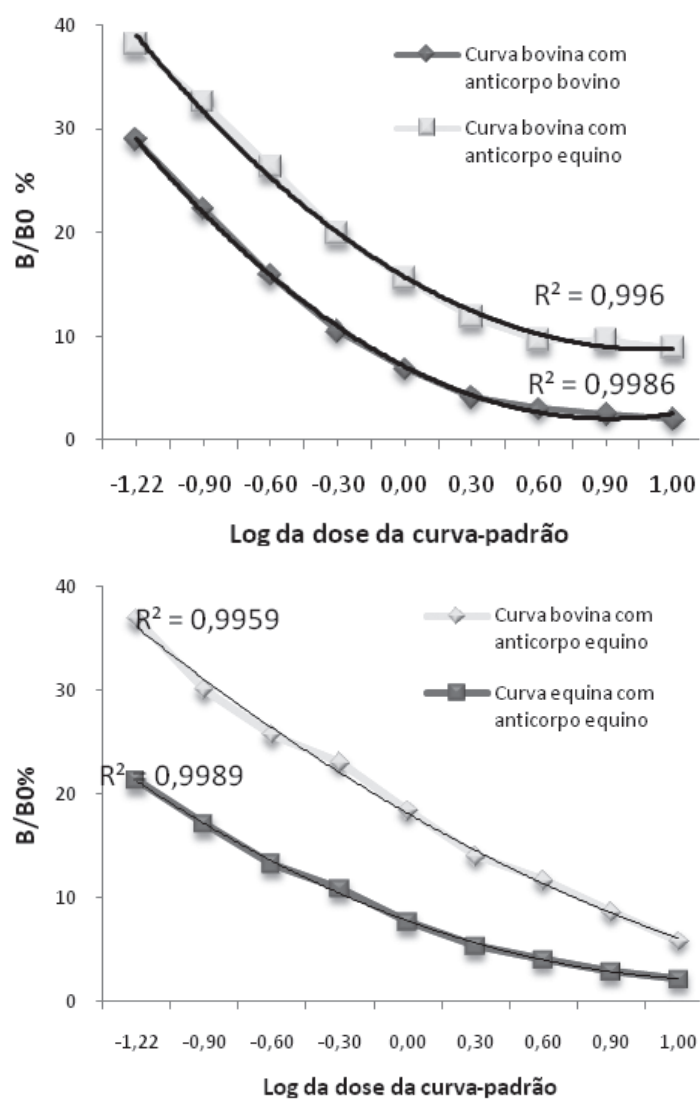

Figura 2 - A: Comparação entre as porcentagens de ligação dos pontos das curvas-padrão elaboradas com r-bLEP e $r$-eLEP em ensaio utilizando anticorpo anti- $r$-eLEP. B: Comparação entre ensaio utilizando anticorpo anti-r-eLEP e ensaio utilizando anticorpo anti-r-bLEP, desafiados com a curva-padrão feita com diluições seriadas de $r-b L E P$ 
por 1; 2 ou $4 \mathrm{~h}$, observou-se o aumento na porcentagem de ligação conforme aumentava o tempo de exposição à alta temperatura $(\mathrm{P}$ $<0,01)$.

Taxa de recuperação ou teste de exatidão: Quando quantidades conhecidas de $r$ - $b \operatorname{LEP}(0,06 ; 0,125 ; 0,25 ; 0,5 ; 1 ; 2$; 4; 8,0 e $10,0 \mathrm{ng} / \mathrm{ml}$ ) foram adicionadas ao tampão, a taxa de recuperação encontrada variou de 98,4 a $101,67 \%$, o que significa que no ensaio realizado essa foi a porcentagem de $r$ - $b L E P$ reconhecida pelo anticorpo anti-r-eLEP.

Teste de efeito matriz: Náo houve diferença na porcentagem de ligação da leptina bovina, presente na curva-padrão, ao anticorpo anti-r-eLEP utilizando tampão de incubaçáo ou tampão de incubação acrescido de $100 \mathrm{ml}$ de plasma bovino com baixas concentraçôes de leptina $(\mathrm{P}>0,3$; Figura 3). Houve correlação $(\mathrm{r}=0,994 ; \mathrm{P}$ $<0,01)$ entre as duas curvas.

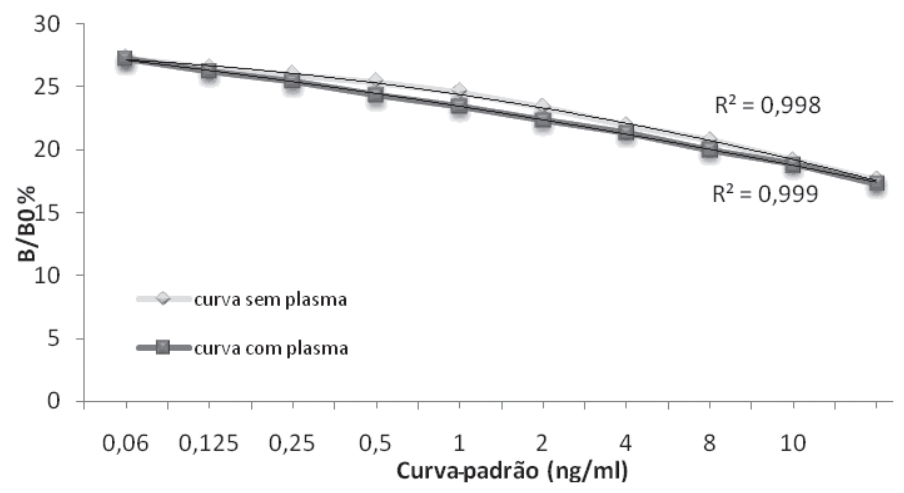

Figura 3 - Comparação da porcentagem de ligação da r-bLEP da curva-padrão ao anticorpo anti- r-eLEP após diluição em tampão de incubação ou em tampão de incubação acrescido de plasma bovino para a curva-padrão

\section{Discussão}

Os resultados obtidos permitiram assumir que o anticorpo anti-r-eLEP é eficiente e apresenta sensibilidade e especificidade suficiente para quantificar leptina bovina. Nos testes de estabilidade, não foi encontrada diferença na porcentagem de ligação quando as amostras foram mantidas à temperatura ambiente ou a $4^{\circ} \mathrm{C}$, o que significa que a permanência por até 7 $\mathrm{h}$ à temperatura ambiente ou 4 dias a $4^{\circ} \mathrm{C}$ não causou alteraçôes à leptina mensurável pelo ensaio ( $p>0,2 ; R 2=0,998)$. A mesma estabilidade não aconteceu conforme se aumentou o período de exposiçáo da amostra a $40^{\circ} \mathrm{C}$, que resultou em um aumento significativo na porcentagem de ligação. Como a porcentagem de ligaçáo da leptina iodada é inversamente proporcional à concentraçáo de leptina presente na amostra, a diminuição na concentração de leptina plasmática em função do tempo de exposição a $40^{\circ} \mathrm{C}$, provavelmente devido a alteraçóes estruturais no hormônio, o impediram de ser reconhecido pelo anticorpo. $\mathrm{Ma}$ et $\mathrm{al}^{5}$, após submeterem amostras a $37^{\circ} \mathrm{C}$, encontraram estabilidade na concentração de leptina plasmática por até 1 dia, ou por 1 semana à temperatura ambiente ou por até 2 meses a $4^{\circ} \mathrm{C}$. A exatidão, obtida com a taxa de recuperação de 98,4 a $101,67 \%$, conferiu ao ensaio confiabilidade, pois por meio dela sabemos que este está sendo eficiente em reconhecer a leptina adicionada com uma variação inferior a $2 \%$. Apesar de não ser possível assumir com precisão que ensaios hormonais utilizando tampão de incubação apresentem resultados similares àqueles obtidos com amostras biológicas ${ }^{13}$, não foi detectada diferença entre as curvaspadrão elaboradas com $r$-bLEP diluída 
em tampão de incubação ou em tampão de incubação acrescido de plasma bovino. Acredita-se que o efeito matriz causado pela ligação de substâncias presentes no plasma, provavelmente proteínas, aumentariam a porcentagem de ligação por aumentarem a formação do precipitado, o que não aconteceria nas amostras da curva diluídas somente em tampão de incubação. Assim, como náo foi encontrado esse efeito no teste realizado, foi adotada para a realização dos ensaios para a quantificação da leptina bovina a curva-padrão diluída em tampão de incubação sem a adição de plasma (Figura 3).

\section{Conclusão}

$\mathrm{O}$ anticorpo antileptina recombinante equina produzido em coelho apresentou sensibilidade suficiente para detectar concentraçóes de leptina circulante no plasma bovino quantificadas pelo RlA e o ensaio para a quantificação de leptina plasmática bovina apresentou sensibilidade, especificidade, precisão e estabilidade, sendo considerado válido e com as características adequadas ao desenvolvimento de um RIA confiável.

\section{Agradecimentos}

À Fundação de Amparo a Pesquisa do Estado de São Paulo - FAPESP (processo 03/11251-4), pela ajuda financeira; aos pesquisadores Carole Delavaud e Yves Chilliard, INRA, França, pelo fornecimento do anticorpo antileptina bovina, utilizado nos testes e à professora Silvia Venturolli Parra, pela ajuda com as análises estatísticas.

\title{
Imunoradioassay validation to plasmatic bovine leptin quantification
}

\begin{abstract}
Due necessity of better understanding leptin and reproduction relations, a specific radioimmunoassay (RIA) to bovine leptin was avalidated. First, an antibody production protocol was developed using recombinant equine leptin inoculated in a rabbit, that results in $28,05 \%$ of maximum binding (MB) 105 days after the protocol beginning. The tests of validations verified parallelism between standard curve and dilutions of high and low controls $(\mathrm{P}<0,01)$. Antibody against equine leptin showed specificity to bovine leptin $(\mathrm{P}<0,01)$. The recuperation tax of bovine leptin by antibody against recombinant equine leptin was from 98,4 to $101,6 \%(\mathrm{P}<0,01)$. When the samples were stored in ambient temperature or refrigerated to $4^{\circ} \mathrm{C}$, ligation stability was verified $(\mathrm{P}>0,2)$, however, temperatures above $37^{\circ} \mathrm{C}$ impaired the bovine leptin recuperation. The use of assay buffer with or without bovine plasma did not show any difference $(P>0,3)$. These results showed that the antibody produced in rabbit against equine leptin were able to detect plasmatic bovine leptin, and that the RIA to bovine leptin quantification had adequate characteristics to the development of a valid assay.
\end{abstract}

\section{Referências}

1 ZHANG, Y.; PROENÇA, R.; MAFFEI, M.; BARONE, M.; LEOPOLD, L.; FRIEDMAN, J. M. Positional cloning ofthe mouse obese gene and its human homologue. Nature, v. 372, p. 425-432, 1994.

2 CAMPFIELD, L. A.; SMITH, F. J.; GUISEZ, Y.; DEVOS, R.; BURN, P. Recombinant mouse OB protein evidence for a peripheral signal linking adiposity and
Keywords: Leptin. Antibody. Radioimmunoassay. Validation. 
cattle and sheep. Journal of Endocrinology, v. 166, p. 519-528, 2000.

5 MA, Z.; GINGERICH, R. L.; SANTIAGO, J. J.; KLEIN, S.; SMITH, C. H.; LANDT, M. Radioimmunoassay of leptin in human plasma. Clinical Chemistry, v. 42, pt. 1, p. 942-946, 1996.

6 BLACHE, D.; TELLAM, R. L.; CHAGAS, L. M.; BLACKBERRY, M. A.; VERCOE, P. E.; MARTIM, G. $B$. Level of nutrition affects leptin concentrations in plasma and cerebrospinal fluid in sheep. Journal of Endocrinology, v. 165, n. 3, p. 625-637, 2000

7 DELAVAUD, C.; BOCQUIER, F.; CHILLIARD, Y.; KEISLER, D. H.; GERTLER, A.; KANN, G. Plasma leptin determination in ruminants: effect of nutritional status and body fatness on plasma leptin concentration assessed by a specific RIA in sheep. Journal of Endocrinology, v. 165, n. 2, p. 519-526, 2000.

8 SAUERWEIN, H.; HEINTGES, U.; HENNIES, M.; SELHORST, T.; DAXENBERGER, A. Growth hormone induced alterations of leptin serum concentrations in dairy cows as measured by a nove I enzyme immunoassay. Livestock Product Science, v. 87, n. 2/3, p. 189-95, 2004

9 PARKER, C. W. Radioimunoassay. Annual Review Pharmacology and Toxicology, v. 21, p. 113-132, 1981.

10 FERREIRA, V. L. M. O radioimunoensaio. Belo Horizonte: Cultura médica, 1983. p. 69-81.

11 HOCKFIELD, S.; CARLSON, S.; EVANS, C.; LEVITT, P.; PINTAR, J.; SILBERSTEIN, L. Selected methods for antibody and nucleic acid probes. New York: Cold Spring Harbour Laboratory Press, 1993. p. 459-501.

12 SALACINSKI, P. R.; MCLEAN, C.; SYKES, J. E.; CLEMENT-JONES, W.; LOWRY, P. J. Iodination of proteins, glycoproteins, and peptides using a solid-phase oxidizing agent, 1,3,4,6-tetrachloro-3 alpha,6 alphadiphenyl glycoluril (lodogen). Analytical Biochemistry, v. 117 , n. 1 , p. $136-146,1981$

13 VAITUKAITIS, J. L.; ROBBINS, J. B.; NIESCHLAG, E.; ROSS, G. T. A method for producing specific antisera with small doses of immunogen. Journal of Clinical Endocrinology and Metabolism, v. 33, p. 988-991, 1971. 